\title{
The Description of Stress Level and Learning Saturation During Online Learning of Nursing Students
}

\author{
Indah Septiana Saputri ${ }^{1}$, Etlidawati $^{2}$ \\ ${ }^{1,2}$ Department of Health, Universitas Muhammadiyah Purwokerto, Indonesia
}

\begin{tabular}{l} 
ARTICLE INFO \\
\hline Article history: \\
DOI: \\
$\underline{10.30595 / \text { pshms.v2i.232 }}$
\end{tabular}

Submitted:

December 6, 2021

Accepted:

January 21, 2022

Published:

January 26, 2022

Keywords:

Learning Saturation; Online Learning For Students; Stress Level

\begin{abstract}
The change in learning models from conventional to online during the Covid19 pandemic is a solution so that the learning process continues. That can make students in a state of stress and boredom. To find a description of the level of stress and boredom of learning in online learning for Nursing students S1 Muhammadiyah University of Purwokerto. This research was descriptive quantitative using survey method. The number of samples were 148 respondents using the proportional stratified random sampling technique. The independent variables in this study were the level of stress and learning saturation. The questionnaire used in this study was a modified DASS-42. The data analysis used univariate analysis. The results showed that the stress levels of students in online learning were mostly in the medium category as many as $88(59.4 \%)$, mild as much as $43(29.1 \%)$, normal as much as 12 $(8.1 \%)$, heavy as much as $5(3,4 \%)$ and no one experienced stress in the very heavy category. Then the level of learning saturation is most dominant in the moderate category as many as $71(48 \%)$, high as much as $40(27 \%)$, low as much as $30(20.3 \%)$, and very high as much as $7(4.7 \%)$. The level of stress and boredom of learning in online learning for third semester undergraduate nursing students is in the medium category. From the results of the study, it is recommended that respondents are be able to anticipate the occurrence of stress and learning saturation by knowing the causes of stress and learning saturation.
\end{abstract}

This work is licensed under a Creative Commons Attribution 4.0 International License.

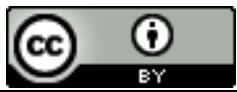

Corresponding Author:

Etlidawati,

Department of Health, Muhammadiyah University of Purwokerto,

Soepardjo Rustam Street KM. 7, Banyumas, Indonesia

Email: etlidawatiump2016@gmail.com

\section{INTRODUCTION}

Currently, the world community is being disturbed by the Corona Virus Diseases (COVID-19) outbreak which has become a pandemic. A pandemic is an epidemic that has spread widely throughout the world or in other words, this outbreak is a problem for people in the world [1]. Many countries have had to take the bitter decision of closing schools to reduce people's contact massively [2]. The government through its circular also ordered all learning activities to be carried out at home (school from home/online). WFH aims to avoid crowds. there are several obstacles in the online learning process faced by students such as no internet network, internet quota running out and assignments piling up. These obstacles often occur when students are in the online learning process.

Hatauruk explained about the obstacles in online learning, including unstable internet networks, limited quotas or expensive internet packages, server downs, stacking tasks, demands to be able to understand the material independently, monotonous learning processes such as delivery models using the method [3]. lectures and there are no varied learning methods, so that the learning process becomes boring, the intonation is less varied, and cannot interact directly with friends or lecturers during the learning process. so that the learning process becomes boring, the intonation is less varied, and cannot interact directly with friends or lecturers during the learning process. 
Based on previous research by Hasanah [4], From the results of this study, it can be concluded that the online learning process can affect student psychology, one of which is student stress levels. The stress that students experience is also called academic stress because of the stress experienced in the learning process. According to Alfiana [5], stress is increasingly becoming a part of our daily lives.

Prolonged or high levels of stress in students may affect memory skills, concentration, problem solving and can cause decreased learning, handling, academic performance, headaches, health problems [6]. Stress experienced by individuals has two factors, namely internal factors and external factors. From these two factors, it can be in the form of demands, namely physical demands or psychological conditions with social demands. This can lead to a mismatch between the demands received and the ability to overcome them [7]. define stress as a condition caused by the interaction of individuals with their environment that causes individuals to see a discrepancy between physical demands or psychological conditions with social demands. A person is said to be stressed if he experiences a burden or task but cannot cope or complete these tasks. The demands that students experience make students feel bored or bored. In a student or students who have to follow the learning process, boredom or boredom is often felt. Study saturation is an emotional condition when a person feels tired and bored mentally or physically [8]

Pawicara said that learning saturation is an emotional and mental condition that is very tired when studying, so that he feels sluggish and is no longer able to accommodate new material or information. For students, the boredom they experience during the online learning process is caused by monotonous delivery of material, less varied intonation, demands to always obey the rules of assignments that accumulate, and cannot interact directly with friends or lecturers [9]. The boredom experienced by students can affect high learning saturation.

The undergraduate nursing students of the Faculty of Health Sciences, University of Muhammadiyah Purwokerto also apply online learning methods. With the change in the learning curriculum for the 2019 class of students, resulted in additional courses and field practice in the batch, by using online learning methods requires students to study extra to achieve maximum learning outcomes. The purpose of this study is to describe of stress level and learning saturation during online learning of bachelor nursing degree of 2019 Universitas Muhamadiyah Purwokerto.

\section{RESEARCH METHOD}

This research method is descriptive quantitative. The population in this study were undergraduate nursing students of the 2019 Faculty of Health Sciences, University of Muhammadiyah Purwokerto, totaling 234 students. The number of samples was 148 respondents using the proportional stratified random sampling technique. The questionnaire used in this study is the modified DASS-42. The data analysis used is univariate analysis.

\section{RESULT AND DISCUSSIONS}

\subsection{Characteristics of Respondents}

Tabel 1. Distribution of characteristics of respondents with stress levels

\begin{tabular}{|c|c|c|c|c|c|c|c|c|c|c|}
\hline \multirow[t]{3}{*}{ Characteristics } & \multicolumn{8}{|c|}{ Stress level } & \multicolumn{2}{|c|}{ Total } \\
\hline & \multicolumn{2}{|c|}{ Normal } & \multicolumn{2}{|c|}{ Weak } & \multicolumn{2}{|c|}{ Medium } & \multicolumn{2}{|c|}{ Strong } & \multirow[b]{2}{*}{$\mathrm{F}$} & \multirow[b]{2}{*}{$\%$} \\
\hline & $\mathrm{f}$ & $\%$ & $\mathrm{~F}$ & $\%$ & $\mathrm{f}$ & $\%$ & $\mathrm{f}$ & $\%$ & & \\
\hline \multicolumn{11}{|l|}{ Age } \\
\hline 18 years old & 1 & 0,7 & 3 & 2,0 & 3 & 2,0 & 0 & 0 & 7 & 4,7 \\
\hline 19 years old & 8 & 5,4 & 29 & 19,6 & 54 & 36,5 & 5 & 3,4 & 96 & 64,9 \\
\hline 20 years old & 3 & 2,0 & 11 & 7,4 & 26 & 17,6 & 0 & 0 & 40 & 27 \\
\hline 21 years old & 0 & 0 & 0 & 0 & 5 & 3,4 & 0 & 0 & 5 & 3,4 \\
\hline Total & 12 & 8,1 & 43 & 29,1 & 88 & 59,5 & 5 & 3,4 & 148 & 100 \\
\hline \multicolumn{11}{|l|}{ Sex/gender } \\
\hline Male & 4 & 2.7 & 14 & 9,5 & 23 & 15,5 & 0 & 0 & 41 & 27,7 \\
\hline Female & 8 & 5,4 & 29 & 19,6 & 65 & 43,9 & 5 & 3,4 & 107 & 72,3 \\
\hline Total & 7 & 8,1 & 43 & 29,1 & 88 & 59,5 & 5 & 20,3 & 148 & 100 \\
\hline
\end{tabular}

Based on this research, most of the students were 19 years old, the number of it was 96 students with the percentage $(64,9 \%)$. While the gender, most of them were female with 107 students $(72,3 \%)$. Based on the results of the cross tabulation of age with stress level, it was found that the most dominant was 19 years old with moderate stress level as many as 54 respondents $(36.5 \%)$. The results based on gender were 
mostly $107(72.3 \%)$, female sex with moderate stress levels were the most dominant as many as 65 respondents $(43.9 \%)$.

Table 2. Distribution of characteristics of respondents with learning saturation

\begin{tabular}{|c|c|c|c|c|c|c|c|c|c|c|}
\hline \multirow{3}{*}{ Characteristics } & \multicolumn{8}{|c|}{ Learning Saturation } & \multicolumn{2}{|c|}{ Total } \\
\hline & \multicolumn{2}{|c|}{$\begin{array}{l}\text { Very } \\
\text { high }\end{array}$} & \multicolumn{2}{|c|}{ High } & \multicolumn{2}{|c|}{ Medium } & \multicolumn{2}{|c|}{ low } & \multirow[b]{2}{*}{$\mathrm{F}$} & \multirow[b]{2}{*}{$\%$} \\
\hline & $\mathrm{f}$ & $\%$ & $\mathrm{f}$ & $\%$ & $\mathrm{f}$ & $\%$ & $\mathrm{f}$ & $\%$ & & \\
\hline \multicolumn{11}{|l|}{ Age } \\
\hline 18 years old & 0 & 0 & 3 & 2,0 & 3 & 2,0 & 1 & 0,7 & 7 & 4,7 \\
\hline 19 years old & 5 & 3,4 & 27 & 18,2 & 42 & 28,4 & 22 & 14,9 & 96 & 64,9 \\
\hline 20 years old & 2 & 1,4 & 7 & 4,7 & 26 & 17,6 & 5 & 3,4 & 40 & 27 \\
\hline 21 years old & 0 & 0 & 3 & 2,0 & 0 & 0 & 2 & 1,4 & 5 & 3,4 \\
\hline Total & 7 & 4,7 & 40 & 27 & 71 & 48 & 30 & 20,3 & 148 & 100 \\
\hline \multicolumn{11}{|l|}{ Sex/gender } \\
\hline Male & 3 & 2 & 11 & 7,4 & 27 & 18,2 & 0 & 0 & 41 & 27,7 \\
\hline Female & 4 & 2,7 & 29 & 19,6 & 44 & 29,7 & 30 & 20,3 & 107 & 72,3 \\
\hline Total & 7 & 4,7 & 40 & 27 & 71 & 48 & 30 & 20,3 & 148 & 100 \\
\hline
\end{tabular}

Based on this research, most of the students were 19 years old, the number of it was 96 students with the percentage $(64,9 \%)$. While the gender, most of them were female with 107 students $(72,3 \%)$. Based on the results of the cross tabulation of age with learning saturation, it was found that the most dominant was 19 years of age with moderate learning saturation as many as 42 respondents $(28.4 \%)$. The results based on gender were mostly female as many as $107(72.3 \%)$, female sex with moderate learning saturation was the most dominant as many as 44 respondents $(29.7 \%)$.

\subsection{Stress level of students in online learning}

Table 3. Students stress level of bachelor nursing degree of 2019

\begin{tabular}{cccc}
\hline & Stress Level & Frequency & Precentage \\
\hline & Normal (0-14) & 12 & 8,1 \\
& Weak $(15-18)$ & 43 & 29,1 \\
& Medium (19-25) & 88 & 59,4 \\
& Strong (26-33) & 5 & 3,4 \\
& Very Strong (>34) & 0 & 0 \\
Total & & $\mathbf{1 4 8}$ & $\mathbf{1 0 0 , 0}$ \\
\hline
\end{tabular}

The level of stress a student bachelor nursing degree of 2019 in online learning mostly in the category of stress were as much as 88 respondents ( $59,4 \%)$.

\subsection{Learning saturation of students in online learning}

Table 4. learning saturation of bachelor nursing degree of 2019

\begin{tabular}{|c|c|c|}
\hline Learning Saturation & Frequency & Precentage \\
\hline Very High $(>65)$ & 7 & 4,7 \\
\hline High (56-65) & 40 & 27,0 \\
\hline Medium (46-55) & 71 & 48,0 \\
\hline Low (36-45) & 30 & 20,3 \\
\hline Very Low $(<35)$ & 0 & 0 \\
\hline Total & 148 & 100,0 \\
\hline
\end{tabular}

A student saturation levels bachelor nursing degree of 2019 mostly dominant in the categories were as much as $71(48,0 \%)$.

\subsection{Characteristics of respondents}

Based on the results of research that has been conducted on 148 respondents, it shows that the respondents in this study were aged 18-21 years with most of the respondents aged 19 years as many as 96 (64.9\%). According to Soesilowindradini [10], said that in the stage of adolescent development, ages 17 to 21 years enter the stage of late adolescent development. Late adolescence is the period of adolescence which will enter early adulthood. According to Santrock [11], states that adolescence is a transitional development 
from childhood to adulthood. With the current pandemic situation, students or college students have to study at home which can cause an increase in negative emotions such as boredom or stress. During this period, the changes that will be experienced by adolescents are cognitive, emotional, and physical changes.

Santrock, says that in adolescence there are several changes such as cognitive, biological, and social emotional changes which are a developmental transition from childhood to adulthood cognitive, biological, and social emotional changes [11]. With the current pandemic situation, students have to study at home which can cause an increase in negative emotions such as boredom or stress. Sahrani [12], the results of the study explain that there is an increase in negative emotions experienced at adolescence such as boredom, stress, depression and anxiety in the online learning system.

Gender in this study is mostly female. In this study, women experienced moderate levels of stress, and the female gender experienced learning saturation in the medium category. According to Tabroni [13], in nursing the majority are female, this is because women's psychology is attached to the motherly spirit (Caring), This is in line with the research conducted by Ayu [14], the proportion of nursing students is dominated by the female sex were friendly, patient, painstaking, and likes to socialize.

\subsection{Stress level of students in online learning}

The level of stress experienced by students in the class of 2019 is in the medium category. moderate stress category lasts from a few hours to a few days. if students are less in coping with stress in the implementation of online learning, it will affect their learning achievement. Moawad explains that in the learning process, stress is one of the most influential factors in achieving good learning achievement [15]. Ahmadi said that stress that cannot be handled optimally will have positive and negative impacts [16]. Meanwhile, according to Andini explained if someone who had a moderate stress status would show increasingly real complaints [17]. Therefore, one of them might be able to reduce the burden of stress so that the body can rest. Dwidiyanti also said that stress symptoms such as physical symptoms, emotional symptoms, and social symptoms [18].

According to Barseli [19], academic stressors are stress that is caused by academics such as the learning process they face, length of study, piling tasks. Puspitasari [20] explained that there were two factors that influence academic stress such as internal factors and external factors, Internal factors such as mindset, personality, beliefs. While external factors such as more dense lessons, pressure for high achievement, support for social status. According to Lubis, said that in online learning there are obstacles experienced by students so that it can have a negative impact, namely students have difficulty concentrating, have difficulty understanding the material, and often procrastinate completing assignments. barriers experienced by students in online learning affect student academic stress [21]. Academic stress is caused by the learning process, piled up tasks, and so on related to academics. Argaheni [22] said that there are several impacts caused by online learning, including online learning that still confuses students, students become passive when learning takes place, the accumulation of information on students is less useful, students experience stress and increase students' language literacy skills. Academic stress can be interpreted as a situation when students cannot face academic demands. This is in line with research conducted by Zhao [6] which says that the level of stress caused in online learning can affect memory levels, concentration, and can experience a decrease in performance in following the learning process.

\subsection{Learning saturation of students in online learning}

The level of learning saturation experienced by students of the class of 2019 is in the medium category. Study saturation is an emotional condition when a person feels tired and bored mentally or physically [8]. Learning boredom can hit students if the student has lost motivation. According to Muna [23], learning saturation has indicators. Indicators in learning saturation such as emotional exhaustion, physical exhaustion, cognitive fatigue, loss of motivation. In addition, learning saturation has several causal factors or factors that affect learning saturation itself. According to Kurniawan [24], explaining that there are six factors that are more likely to lead to burnout at school, such as the demands of assignments from schools that are too many so that students often feel burdened. Non-creative learning methods and limited student participation so that students get bored quickly, lack of praise or rewards are very important for motivation and progress for students, interpersonal relationships are not well established, between teachers and students as well as students, expectations or high from, many students in life in failure, and lack of success, the existence of values and norms that exist at school with the rules that exist at home.

Based on the results of the analysis of answer choices, respondents felt the most from the 20 questions that had the highest answer choices in the frequent answer choices as many as 11 questions (55\%). For students, the boredom experienced during the online learning process is caused by monotonous delivery 
of material, less varied intonation, this can be seen in the aspect of losing motivation, it is found that the most dominant is in the medium category $(36.5 \%)$

The problem of student learning saturation who cannot interact directly with friends or lecturers is supported by the most dominant aspect of cognitive loss in the moderate category $(39.2 \%)$.

Another study also conducted by Pawicara [9] said that when online learning, the media or material presented was less attractive so that the online learning process was carried out monotonously, the number of tasks given and material was only given without in-depth explanation, this can causes boredom of learning in students

Boateng [25] in his research on prevalence and changes in boredom, anxiety and well-being among Ghanaians during the COVID-19 pandemic: a population-based study. The results showed that before the COVID-19 pandemic that $63.5 \%$ reported better well-being, $11.6 \%$ symptoms of anxiety, and $29.6 \%$ symptoms of burnout.

\section{CONCLUSION}

Based on the results and discussion of the research that has been carried out, it can be concluded that the age of the 2019 undergraduate Nursing students is mostly 19 years old (64.9\%) with the sex being mostly female $(72.3 \%)$. The stress level of the 2019 undergraduate Nursing students in online learning is mostly in the moderate stress category (59.4\%). The saturation level of the 2019 undergraduate Nursing students was the most dominant in the medium category $(48.0 \%)$. Students are expected to reduce learning saturation and stress to better manage time when there are more assignments.

\section{Acknowledgements}

Thanks to Allah SWT, both parents and all comrades in arms who have helped from beginning until the end, Furthernore, thank to the supervisors, examiners and institutions that have made my research easier to be completed.

\section{REFERENCES}

[1] F. G. Winarno, "COVID_19 Pelajaran Berharga dari Sebuah Pandemi," 2020.

[2] R. H. Aji, "Dampak Covid-19 pada Pendiidkan di Indonesia: sekolah keterampilan dan proses pembelajaran," vol. 7, 2020.

[3] A. \&. S. R. Hutauruk, "Kendala Pembelajaran Daring Selama Masa Pandemi di Kalangan Mahasiswa Pendidikan MAtematika: kajian kualitatif Deskriptif," Journal of Mathematics Education and Applied, vol. 2, pp. 45-51, 2020.

[4] U. L. I. \&. L. Hasanah, "Gambaran Psikologi Mahasiswa dalam Proses pembelajaran Selama Pandemi Covid-19," Jurnal Keperawatan Jiwa, vol. 8, no. 3, pp. 299-306, 2020.

[5] I. Alfiana, "Coping Stress Mahasiswa Praktikum di Tinjau dari Jenis Kelamin," Universitas Muhammadiyah Surakarta, Surakarta, 2018.

[6] Z. e. al, "Academic stress in Chinese schools and a proposed preventive intervention program," Cogent Education, 2015.

[7] E. P. \&. S. T. W. Sarafino, Health Psychology, Biopsychososial, 2012.

[8] A. K. S. \&. M. M. R. Astaman, "Upaya mengatasi kejenuhan belajar (tinjauan pendidikan islam pada SDN 10 Banawa Kabupaten Donggala)," Jurnal Kolaboratif Sains, vol. 1, no. 1, pp. 983-993, 2018.

[9] R. \&. C. M. Pawicara, "Analisis pembelajaran daring terhadap kejenuhan belajar mahasiswa tadris biologi IAIN jember di tengah pandemi covid-19," Jurnal Pendidikan Biologi, vol. 1, no. 1, pp. 29-38, 2020.

[10] Soesilowindradini, Psikologi Perkembangan (Masa Remaja), Surabaya: Usaha Nasional, 2019.

[11] J. Santrock, Educational Psychology, McGraw: Hill Education, 2018.

[12] R. d. Sahrani, Tinjauan pandemic Covid-19 dalam psikologi perkembangan, Aceh: Syiah Kuala University Press, 2020.

[13] I. N. F. A. \&. A. A. Tabroni, "Gambaran Tingkat Stres dan Stresor pada Mahasiswa Keperawatan Universitas Negeri di Provinsi Riau," Jurnal Keperawatan, vol. 13, no. 1, pp. 149-164, 2021.

[14] D. Ayu, "Hubungan Persepsi Mahasiswa tentang Profesi Keperawatan dengan Motivasi Melanjutkan Pendidikan Profesi Ners di PSIK Universitas Jember," e-Jurnal Pustaka Kesehatan, vol. 5, no. 3, 2017. 
[15] R. A. Moawad, "Online learning during the COVID-19 pandemic and academic stress in university student," Revista Românească pentru Educaţie Multidimensională, vol. 12, no. 1, pp. 100-107, 2020.

[16] A. H. \&. S. W. Ahmadi, Psikologi Belajar, Jakarta: Rineka Cipta, 2013.

[17] N. F. Andini, "Dampak Pembelajaran Daring Bagi Mahasiswa Masa pandemic Covid-19," Universitas Negeri Makassar, Makassar, 2020.

[18] M. P. Y. F. \&. N. H. E. W. Dwidiyanti, Mindfulness Caring, Semarang: UNDIP PRESS, 2018.

[19] M. Barseli, "Konsep Stres Akademik Siswa," Jurnal Konseling dan Pendidikan, pp. 2337-6740, 2017.

[20] W. (. Puspitasari, "Hubungan antara manajemen waktu dan dukungan ocial dengan prestasi akademik mahasiswa yang bekerja," EMPATHY Jurnal Fakultas Psikologi, vol. 2, no. 1, 2013.

[21] H. Lubis, "Stres Akademik Mahasiswa dalam Melaksanakan Kuliah Daring Selama Masa Pandemi Covid 19," Psikostudia Jurnal Psikologi , vol. 10, no. 1, pp. 31-39, 2021.

[22] N. B. Argaheni, "Sistematik review: dampak perkuliahan daring saat pandemi Covid-19 terhadap mahasiswa Indonesia," Jurnal Ilmiah Kesehatan dan Aplikasinya, vol. 8, no. 2, pp. 99-108, 2020.

[23] N. R. Muna, "Efektivitas teknik self regulation learning dalam meredukasi tingkat kejenuhan belajar siswa di SMA Insan Cendekia Sekarmuning Cirebon," Holistik, vol. 14, no. 2, pp. 57-78, 2013.

[24] N. G. Kurniawan, "Efektivitas musik klasik (mozart) untuk menurunkan kejenuhan belajar siswa kelas XI SMAN 4 Yogyakarta," Jurnal Riset Mahasiswa Bimbingan Dan Konseling, vol. 5, no. 7, 2016.

[25] G. O. e. a. Boateng, "Prevalence and changes in boredom, anxiety and well-being among Ghanaians during the covid-19 pandemic: a population-based study," BMC public health, vol. 21, no. 1, pp. 1-13, 2021 . 